\title{
THE MARKET POWER OF DIGITAL CONSUMERS IN 24/7/365 CONNECTED WORLD
}

This paper analyzes and presents the sources of the market power of digital consumers and marketing opportunities for companies in the 24-7-365-connected world. A research was conducted into the impact of students connected via the social media on changes at the faculty, civil society and social change. Market power is being redirected from companies to digital consumers. Key sources of digital consumers' power are their abundance, connectivity with other consumers, increased awareness, mobility, and as a result - the control of communications and the impact on organizations' business. Numerous, connected, informed and mobile consumers can control communications and the business of companies. Digital consumers have the power and it should not be seen as a threat but as an opportunity. This is why the sources of market power of digital consumers and marketing opportunity are presented as a honeycomb. The conclusion can be drawn that digital consumers have market power only if they are connected to each other and aware of their power. Figuratively speaking, "one bee can achieve almost nothing but the bee community can." The similar thing happens with digital consumers.

Keywords: digital consumers, social media, market power, connected world, marketing opportunities

Faculty of Business Studies, Megatrend University, Belgrade, Serbia; mrakic@megatrend.edu.rs Faculty of Business Studies, Megatrend University, Belgrade, Serbia; brakic@megatrend.edu.rs 


\section{Introduction}

Access to technology and the Internet is having a positive impact at all levels - the personal, the family, the professional and the social ones. ${ }^{1}$ The changes in WEB environment cause changes in the power of the actors on market and civil society. Numerous users of the social media (social networks in particular) in different locations can fast connect with each other, communicate with one another in real time and engage themselves in different manners, ranging from informing to organizing online and offline events. ${ }^{2}$ Digital consumers can use social media and digital communications to make impacts on the business doing of companies, civil society and social change. Consumers can invite people not to buy certain products, boycott some companies, follow certain consumption patterns (e.g. buy organic food) etc. Students can gather together and mobilize themselves via social media in order to pursue their goals and have an impact on the work of the faculty, civil society and social change. Users of social media could "foster people's political engagement" and "contribute to transforming social injustices and inequalities". ${ }^{3}$ Consumer online behavior is developing fast. Today, consumers in social media are involved in a wide range of different activities, ranging from consuming content to taking part in discussions, sharing knowledge with other consumers, and contributing to activities carried out by other consumers. ${ }^{4}$ Users of the digital media in their different roles (as students, the employed, consumers, members of civil society etc.) can have an influence on civil society and social change via digital communications. This paper is focused on the sources of the powers of digital consumers, their impacts on companies and marketing opportunities for companies.

"Web 2.0 " is an umbrella term that is used to refer to a new era of Webenabled applications that are built around user-generated or user-manipulated content, such as wikis, blogs, podcasts, and social networking sites. ${ }^{5}$ The stated definition of Web 2.0 emphasises the power of users. In addition to the usual term: user-generated content, the term user-manipulated content is also used. Users can create but also to manipulate the content. Denning ${ }^{6}$ explains that there

$1 \quad$ Ruiz, R.G., García, A.R., Rosell, M.M.R. (2014): "Media Literacy Education for a New Prosumer Citizenship.” Comunicar Journal, 43, 15-23.

$2 \quad$ Aldás, E.N., Murphy, J.M. (2013): “Occupy Movements and the Indignant Figure.” Peace Review - A Journal of Social Justice, 25, 333-335.

3 Ibid, 335.

4 Heinonen, K. (2011): “Consumer activity in social media: Managerial approaches to consumers' social media behavior." Journal of Consumer Behaviour, 10, 356-364.

5 Pew Internet \& American Life Project. (2013): Web 2.0. Available at http://www. pewinternet.org/topics/Web-20.aspx?typeFilter $=5$

6 Denning, S. (2010): "Managing the threats and opportunities of the open corporation." Strategy \& Leadership, 38, 16-22. 
has been a fundamental shift in the balance of power in the marketplace from sellers to buyers so that buyers gain power. In the twentieth century, companies had control of the marketplace but web technology has generated changes. Now, buyers have instant access to reliable information. Aprimo ${ }^{7}$ explains it is not just the media landscape that has evolved - it is the customer as well. Now, the customer has empowered role, and that means that customer is active, engaged and in control of the conversation. Yesterday's passive consumer has been replaced by one who is active, engaged and in control of how he or she encounters marketing communication. ${ }^{8}$ The growth of social media enabled companies to impose unnecessary harm upon their businesses by not paying attention to consumer-generated advertisements and the influence of communicative technology on their products. This new trend in consumer behaviour must be recognized by companies and they should take advantage of consumer efforts to promote their brands by adjusting their marketing strategies so as to utilize this trend. ${ }^{9}$ Fish ${ }^{10}$ says - at the heart of social media channels is the power to the people. Schiller ${ }^{11}$ notes that the web is rapidly being redeveloped as a consumer medium. In an interview with Brian Solis, Klout CEO Joe Fernandez said, "We live in an amazing time where the power has shifted to the individual. You mix blindness to advertising, the scale of word of mouth, and the empowered consumer, and now you have a situation where every interaction between a brand and a person is the story that's created about that brand," Fernandez added. As power continues to shift from large organizations to individuals, and brand trust becomes harder to establish, conversations and recommendations have become like a form of currency. Consumers generated more than 500 billion impressions about products and services through social media in 2011, according to Forrester Research's study "Competitive Strategy In The Age Of The Customer." Understanding how customers and potential customers behave online, and why, is going to become increasingly important for companies. Understanding how they interact directly and indirectly with a brand is going to become even more important in the pursuit of cultural and personal relevance. "New media penetrate into so many areas of society and permeate social cohabitation so

Aprimo (2011): Insights to Help Advance Digital Marketing. Available at http://research. itpro.co.uk/content 12192

$8 \quad$ Ibid.

9 Pehlivan, E., Sarican, F., Berthon, P. (2011): "Mining messages: Exploring consumer response to consumer- vs. firm-generated ads." Journal of Consumer Behaviour, 10, 313-321.

10 Fish, J. (2010): "Power to the People Is at the Heart of Social Media Channels!" Credit Union Times, 21, 10.

11 Schiller, D. (1999): "Deep impact the web and the changing media economy." Info - The journal of policy, regulation and strategy for telecommunications, 1, 35-51.

12 Contreras, E. (2013): Social State: Thoughts, stats, and stories about the state of social media in 2013. Social Nerdia, 189-190. 
deeply that the investigation of associated (social psychological) phenomena has become a prolific field of research and is likely grow further in the future". ${ }^{13}$

The structure of this paper is as follows. Section 1 presents the sources of power and reviews the relevant literature in order to construct hypotheses. Section 2 presents the method. Section 3 investigates hypotheses about of power of digital consumers. Section 4 briefly summarises the paper and its contributions.

\section{The sources of market power of digital consumers}

The development of digital technologies influences consumers' behaviour. From the perspective of the companies, the key challenges in the area of consumers' behaviour in the digital environment are: abundance, the ability to connect with other consumers, increased awareness, mobility, and as a result the control of communications and the impact on companies' business. Figure 1 shows the six key sources of consumers' power. The result is a huge potential for informed and connected digital consumers.

First, the number of digital consumers is large. Second, the digital technologies allows consumers to connect with each other, exchange information and experiences, influence companies, events, persons etc. regardless of the geographic location, primarily through social media (networking sites, blogs, etc.), but in some other ways, too. Third, the consumers quickly and easily obtain information, are enabled to follow current events ("live"), compare information and make better decisions. Fourth, wireless and mobile devices make mobile consumers, i.e. they allow the consumer to always be available everywhere, which is most important for the consumer if they want to be available. Fifth, consumers can control communications and thus influence the online image of brands and companies. Sixth, numerous, connected, informed, educated and interested in the impact, consumers can have greater power than companies and they can influence the business. However, on one hand consumers are often unaware of their power, potential, and on the other hand, the initiators - the leaders who will initiate and encourage consumers to certain activities are needed.

13 Batinic, B., Goritz, A. (2009): “How Does Social Psychology Deal with New Media.” Social Psychology, 40, 3. 
Figure 1. The honevcomb of the power of digital consumers.

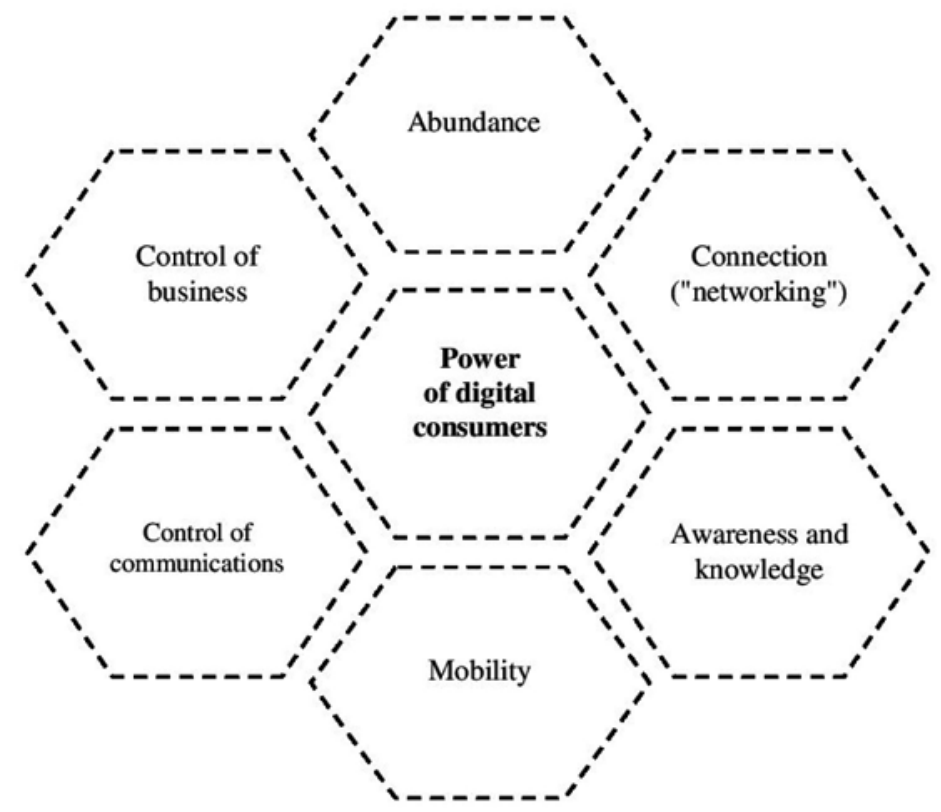

Source: Rakić and Rakić, 2015.

These sources of power of digital consumers should not be seen as a threat, but as a marketing opportunity. As consumers have increasingly been conducting activities that were previously controlled by companies, the entire marketing environment has started to change. Therefore, companies need to understand consumer's changing behaviour better in order to create mutual benefits from the harnessing of social media. ${ }^{14}$ As BBC Business Editor Tim Weber ${ }^{15}$ explains: "It's a dramatic shift in consumer power. But what if companies could harness this power and turn it to their advantage?" Marketing opportunity for companies based on the marketing power of digital consumers is presented in Figure 2. Social media marketing leads to the increase of the number of consumers as users of social media. A company can "direct" communications and contribute to the additional connecting of users as users of social media (customer community) on the basis of the marketing community. Content marketing influences the awareness and knowledge of customers. Mobile marketing encourages mobile communications. A company cannot control social media communications, but it can direct and influence them. Interactions with users of

14 Heinonen, K. (2011): "Consumer activity in social media: Managerial approaches to consumers' social media behavior.” Journal of Consumer Behaviour, 10, 356-364.

15 Weber, T. (2010): Why companies watch your every Facebook, YouTube, Twitter move. Available at http://www.bbc.co.uk/news/business-11450923 
social media and word of mouth marketing (WOMM) influence word of mouth (WOM) communications which are favoured by companies. The engagement and collaboration with the users of social media lead to good business for both the consumers and the companies.

Figure 2. Opportunities for companies on the basis of honeycomb of digital consumers' power.

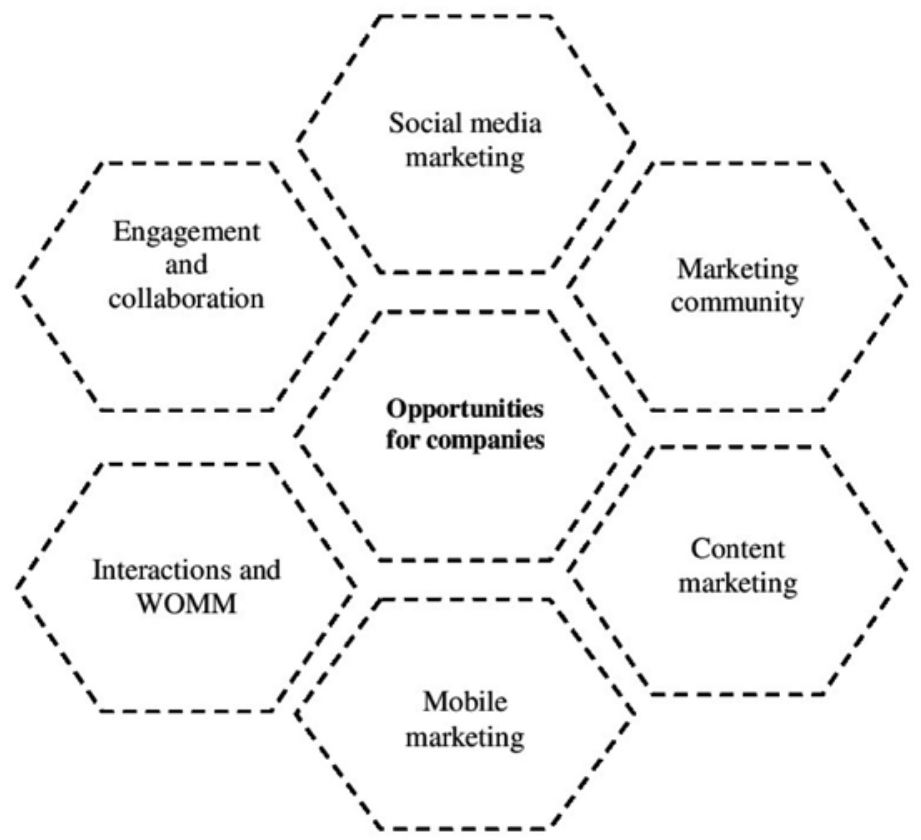

Source: Rakić and Rakić, 2015.

\subsection{Abundance}

There are almost 3.9 billion Internet users, i.e. $51.7 \%$ of the total population in the world according to the data from June $2017 .{ }^{16} \mathrm{Kim}$, Jeong and Lee ${ }^{17}$ states that today hundreds of millions of Internet users are using thousands of social Web sites to stay connected with their friends, discover new "friends" and to share user-created contents, such as photos, videos, social bookmarks, and blogs. "Social networks are now the operating systems for consumers' lives. They have rapidly become indispensable." says Ajaz Ahmed, chairman and founder

$16 \quad$ Internet World Stats. (2017): World Internet Users and 2017 Population Stats. Available at http://www.internetworldstats.com/stats.htm

17 Kim, W., Jeong, OR., Lee, SW. (2010): “On social Web sites.” Information Systems, 35, 215-236. 
of AKQA, one of the world's leading digital advertising agencies. ${ }^{18}$ The Market is made of people - consumers. The data shows that the number of the Internet users is great. However, users of the Internet and especially social media do not have to be a certain brand consumers. The data on the number of potential and actual consumers who are not only Internet users but are also active through social media are even more important. According to the statistics ${ }^{19}$ on the Top 25 Facebook Pages Lists, there are two Facebook's own fan pages that ranked first and second in November 2015 (Facebook for Every Phone and Facebook). Cristiano Ronaldo, as the most popular person on Facebook (107 348909 total fans, in November 2015), ranked third, and musical icon Shakira (103 035465 total fans, in November 2015) is ranked the fourth. On the Top 25 Facebook Pages List, entertainment pages are predominant (Shakira, Vin Diesel, Eminem, Rihanna, Michael Jackson, etc.), popular soccer teams and players (Cristiano Ronaldo, FC Barcelona, Real Madrid, Leo Messi, Manchester United, etc.). Coca-Cola, ranked the sixth, singles out amongst companies (93533055 total fans, in November 2015). ${ }^{20}$

\subsection{Opportunities to connect with other consumers}

The number of Internet users is even more important if such numerous users are connected with each other. Hanna, Rohm and Crittenden ${ }^{21}$ note that in the 21st century connected consumer marketplace, we are all connected, so the social media ecosystem has the power. They add that interactive digital media platforms are changing the marketing landscape, and the nature and sources of information and connectivity are vast, in effect creating a 24/7 collaborative world. These platforms have empowered consumers to connect, share, and collaborate, creating spheres of influence that have fundamentally altered the way marketers engage in influencing activities. ${ }^{22}$

$18 \quad$ Vollmer, C., Premo, K. (2012): From Campaigns to Capabilities-The Impact of Social Media on Marketing and Beyond, Booz \& Company Inc. Available at http://www.booz. com/global/home/what-we-think/reports-white-papers/article-display/from-campaignscapabilities-impact-social, 4.

19 Socialbakers. (2015): Facebook Pages Stats. Available at http://www.socialbakers.com/ statistics/facebook/pages/total/page-1-3/

$20 \quad$ Ibid.

$21 \quad H a n n a$, R., Rohm, A., Crittenden, V. (2011): “We're all connected: The power of the social media Ecosystem.” Business Horizons, 54, 265-273.

22 See: Alberici, AI., Milesi, P. (2013): “The Influence of the Internet on the Psychosocial Predictors of Collective Action." Journal of Community \& Applied Social Psychology, 23, 373-388.; Aldás, E.N., Murphy, J.M. (2013): "Occupy Movements and the Indignant Figure.” Peace Review - A Journal of Social Justice, 25, 333-335.; Aldás, E.N., Pinazo D. (2013): "Communication and Engagement for Social Justice." Peace Review - A Journal of Social Justice, 25, 343-348.; Aragon-Correa, J.A., Cordon-Prozo, E. (2005): “The influence of strategic dimensions and the environment on the introduction of internet as innovation into small and medium-sized enterprises." Technology Analysis and Strategic Management,

Vol. 16, № 2, 2019: 79-100 
The connectivity of consumers allows consumer-to-consumer communications and e-Word of Mouth (e-WOM). Segbers ${ }^{23}$ speaks about exponential power of WOM via Internet. Mangold and Faulds ${ }^{24}$ states that the emergence of Internet-based social media has made it possible for one person to communicate with hundreds or even thousands of other people about the companies and the products each one provides. Thus, the impact of consumer-to-consumer communications has been greatly magnified in the marketplace. Social media pro-

17, 2205-218.; August, C., Liu, J.H. (2015): “The Medium Shapes the Message: McLuhan and Grice Revisited in Race Talk Online.” Journal of Community \& Applied Social Psychology, 25, 232-248.; Galera, C.G., Hurtado, M.H., Muñoz, C.F. (2014): "Engaged Youth in Internet. The Role of Social Networks in Social Active Participation." Comunicar Journal, 43, 35-43; Hamill, A.C., Stein, C.H. (2011): "Culture and empowerment in the Deaf community: An analysis of internet weblogs." Journal of Community \& Applied Social Psychology, 21, 388-406.; Hanna, R., Rohm, A., Crittenden, V. (2011): "We're all connected: The power of the social media Ecosystem." Business Horizons, 54, 265-273.; Niland, P., Lyons, A.C., Goodwin, I., Hutton, F. (2015): "Friendship Work on Facebook: Young Adults' Understandings and Practices of Friendship." Journal of Community \& Applied Social Psychology, 25, 123-137.; Obst, P., Stafurik, J. (2010): "Online we are all able bodied: Online psychological sense of community and social support found through membership of disability-specific websites promotes well-being for people living with a physical disability." Journal of Community \& Applied Social Psychology, 20, 525-531.; Rakic, B., Rakic, M. (2015): Digitalni marketing - integrisani pristup digitalnim marketinskim aktivnostima, monografija. Beograd: Zavod za udzbenike.; Rakic, B., Rakic, M. (2017a): From Marketing Myopia to Contemporary Marketing: Transformations in Marketing in the Context of Digitalization and Sustainability (Integration of Traditional, Digital, Co-Creative and Sustainability-Oriented Mindsets Inside Actors in Contemporary Marketing). E-Book, available at eBook retailers: Amazon.com - Kindle Store, etc.; Kindle Edition ASIN: B06WGV26DT https://www.amazon.com/Marketing-MyopiaContemporary-Through-Evolutions-ebook/dp/B06WGV26DT/ref=sr_1_2?s=digitaltext\&ie $=\mathrm{UTF} 8 \& q i d=1487803402 \& \mathrm{sr}=1-2 \&$ keywords=marketing+myopia or https://www . books2read.com/u/bMGKkk; Rakic, B., Rakic, M. (2017b): Facebook or the "Book of Faces" as a database for customer profiles, marketing communications and applications. 21st International Scientific Conference on Economic and Social Development. Book of Proceedings: Economic and Social Development, 48-58.; Siddiquee, A., Kagan, C. (2006): "The internet, empowerment, and identity: an exploration of participation by refugee women in a Community Internet Project (CIP) in the United Kingdom (UK)." Journal of Community \& Applied Social Psychology, 16, 189-206.; Singh, T., Veron-Jackson, L., Cullinane, J. (2008): "Blogging: A new play in your marketing game plan." Business Horizons, 51, 281-292.; Su, P., Wang, L., Yan, J. (2018): “How users' Internet experience affects the adoption of mobile payment: a mediation model." Technology Analysis and Strategic Management, 30, 186-197.; Walmsley, A. (2010): New media needs new PR. Available at http://www.marketingmagazine.co.uk/article/985566/andrew-walmsleydigital-new-media-needs-new-pr

23 Segbers, R. (2010): “Go where the customers are - Marketing (and managing) your patient experience with social media”. Marketing health services, 30, 22-25.

24 Mangold, G., Faulds, D. (2009): "Social media: The new hybrid element of the promotion mix.” Business Horizons, 52, 357-365. 
vide an interactivity platform to consumers, and interactivity leads to consumer empowerment by giving the consumer a platform to vote for themselves. ${ }^{25}$

As Aula ${ }^{26}$ explains - social media is characterised by interactivity participants freely send, receive, and process content for use by others. Anklam ${ }^{27}$ adds that linking - ideas and people - is a pivotal force in our shifting social context. Linking, commenting and connecting with people stimulates a truly global and boundary-less knowledge network. Stowe Boyd coined the term "social tools" in 1999 as "... generation of software...designed from the start to guide human behaviour into new paths and patterns, to counter prevailing ways of interaction". ${ }^{28}$ For now, as O'Hare and Murdock ${ }^{29}$ explains we lead a double life in parallel social systems. First, in our offline life - in our everyday experience, we have friends, family, events, and social connections that happen in the real world that enrich and give meaning to our lives. Second, in our online life - we also have friends, family, events and social connections that exist primarily online, which also enriches and gives meaning to our lives. Third, viewed integrally, in our double life in parallel social systems - for most of us, our online life and our offline life have points of intersection such as events that we arrange online, but that take place offline, or places that we visit and then photograph, discuss, and share with our online social community. ${ }^{30}$

\subsection{Awareness and knowledge}

People have been referring to social networks as an increasingly common way to have their information shared and to seek emotional support for different issues, such as, for example, health problems (e.g. weight loss etc.), ${ }^{31}$ and product purchase and so on. Content is one of the essential reasons for connectivity. Numerous and connected digital consumers can quickly exchange much more information thus contributing to the knowledge about e.g. brands. In this way they affect the reputation of brands online.

25 Pehlivan, E., Sarican, F., Berthon, P. (2011): "Mining messages: Exploring consumer response to consumer- vs. firm-generated ads." Journal of Consumer Behaviour, 10, 313-321. Aula, P. (2010): "Social media, reputation risk and ambient publicity management." Strategy \& Leadership, 38, 43-49. Anklam, P. (2009): “Ten years of net work.” The Learning Organization, 16, 415-426.

28 Ibid.

29 O’Hare, N., Murdock, V. (2012): “Modeling locations with social media.” Information Retrieval, 16, 30-62.

$30 \quad$ Ibid.

$31 \quad$ Ballantine, P.W., Stephenson, R.J. (2011): "Help me, I’m fat! Social support in online weight loss networks." Journal of Consumer Behaviour, 10, 332-337. 


\subsection{Mobility}

We live in a world which provides opportunities for ongoing communications and connections - 24/7/365. As Scott ${ }^{32}$ explains - while Facebook, Twitter, and LinkedIn are the most recognized of the social media, other related sites like Foursquare, iMeet, and Mashable are exploding on the scene with great fan fare. Amidst this tsunami of tech applications are legions of mobile devices like smart phones, laptops and iPads that allow users to interact with social media remotely, 24/7/365.

\subsection{The control of communications}

Many authors speak about the inability of companies to control the communications about their brands. As Mangold and Faulds ${ }^{33}$ state, consumers' ability to communicate with one another limits the amount of control companies have over the content and dissemination of information. Also, Vollmer and Precourt ${ }^{34}$ note that in the era of social media "consumers are in control; they have greater access to information and greater command over media consumption than ever before". This shift in the information control needle is dramatically influencing the way consumers receive and react to market information..$^{35}$ Consumers are no longer merely passive recipients in the marketing exchange process. Today, they are taking an increasingly active role in co-creating marketing content with companies and their respective brands. ${ }^{36}$ "The rise in interactive digital media has catapulted company and consumer contact from the traditional Web 1.0 model to the highly interactive Web 2.0 world, where consumers are dictating the nature, extent, and context of marketing exchanges". ${ }^{37}$ The freedom provided

32 Scott, M. (2011): “Social Media Flurry”. OfficePro, 71, 38-41.

33 Mangold, G., Faulds, D. (2009): "Social media: The new hybrid element of the promotion mix." Business Horizons, 52, 357-365.

34 Vollmer, C., Precourt, G. (2008): Always on: Advertising, marketing, and media in an era of consumer control. McGraw-Hill: New York, 5.

35 See: Mangold, G., Faulds, D. (2009): "Social media: The new hybrid element of the promotion mix.” Business Horizons, 52, 357-365.; Ramsey, G. (2006): Digital marketing strategies in the age of consumer control.http://www.asc.upenn.edu/courses/comm530/ secure/Fall\%202006/Digital\%20Marketing\%20Strategies.pdf; Singh, T., Veron-Jackson, L., Cullinane, J. (2008): "Blogging: A new play in your marketing game plan.” Business Horizons, 51, 281-292.

36 Berthon, P.R., Pitt, L.F., McCarthy, I., Kates S. (2007): When customers get clever: Managerial approaches to dealing with creative consumers. Business Horizons, 50, 39-48.; Hanna, R., Rohm, A., Crittenden, V. (2011): "We're all connected: The power of the social media Ecosystem.” Business Horizons, 54, 265-273.

37 Hanna, R., Rohm, A., Crittenden, V. (2011): "We're all connected: The power of the social media Ecosystem.” Business Horizons, 54, 265. 
by social media empowers the consumer to make their voice heard..$^{38}$ Aula ${ }^{39}$ talks about the problem of communications control in terms of strategic reputation management. In terms of strategic reputation management, what is important is that social media content cannot be controlled in advance and that content cannot be managed in the same way as, for example, conventional media such as TV or newspapers. In practice, this means that it is almost impossible for organizations to control conversations about themselves. Chen, Fay and Wang ${ }^{40}$ explain that social media provide an unparalleled platform for consumers to publicize their personal evaluations of purchased products and thus facilitate word-ofmouth communication. Based on WOM communication, consumers can influence to a great extent the online, and thus the overall image of an organisation.

The control of communications by consumers should not be seen as a threat, but as an opportunity for communications to be on equal terms with consumers. Booth and Matic ${ }^{41}$ explain that control is an illusion. Companies cannot control the conversations with social media, but they can influence them. This is why mapping and leveraging influencers in social media to shape corporate brand perceptions is very important.

Because of the changes in environment, Denning ${ }^{42}$ posts a question: How are corporate leaders to reconcile the need to preserve appropriate control and confidentiality with today's seemingly inexorable pressure to manage, communicate and share information more openly? As Denning ${ }^{43}$ suggests: To defend against the threats and to take advantage of the opportunities posed by social media, senior leaders need to understand how to manage in identifies six elements of openness in terms of information sharing:

- Explaining - giving the reasons for what is happening.

- Updating - passing on new information.

- Conversing - interacting with people.

- "Open mic" - letting everyone have her or his say.

- Crowd-sourcing - seeking ideas from a larger crowd.

- Platforms - to set standards and share data.

38 Pehlivan, E., Sarican, F., Berthon, P. (2011): "Mining messages: Exploring consumer response to consumer- vs. firm-generated ads." Journal of Consumer Behaviour, 10, 313-321.

39 Aula, P. (2010): "Social media, reputation risk and ambient publicity management." Strategy \& Leadership, 38, 43-49.

40 Chen, Y., Fay, S., Wang, Q. (2011): “The Role of Marketing in Social Media: How Online Consumer Reviews Evolve." Journal of Interactive Marketing, 25, 85-94.

41 Booth, N., Matic, J. (2011): "Mapping and leveraging influencers in social media to shape corporate brand perceptions." Corporate Communications: An International Journal, 16, 184-191.

42 Denning, S. (2010): "Managing the threats and opportunities of the open corporation." Strategy \& Leadership, 38, 16-22.

43 Ibid.

Vol. 16, № 2, 2019: 79-100 


\subsection{The Control of Business}

"It is widely recognized that many different opes and forms of knowledge contribute to technology development". "You have to be on 24/7," noted a senior executive with a major apparel brand. "You have to respond to customers all the time. Issues escalate so fast, you can be held hostage by someone in social media." ${ }^{45}$ The authors have added - furthermore, once visitors become fans, companies have the responsibility to listen to them and reward their behaviour with an "always on" social media experience that is responsive, interesting, and attentive. If not, companies may face disappointment and disfavour from many of their most valued consumers. ${ }^{46}$ Digital environments are commonly depicted as sites of consumer empowerment, participation, co-creation and prosumption the intertwined process of production and consumption. ${ }^{47}$ Since Toffler ${ }^{48}$ has first invented the term the "prosumer," numerous authors talk about the importance of prosumers and prosumption, prosumer age, age of the digital prosumer, prosumer capitalism ${ }^{49}$ and co-creation..$^{50}$ Prosumer is the one who is both the

$44 \quad$ Fleck, J. (1997): “Contingent knowledge and technology development. Technology Analysis and Strategic Management, 9, 383-398.

45 Vollmer, C., Premo, K. (2012): From Campaigns to Capabilities-The Impact of Social Media on Marketing and Beyond, Booz \& Company Inc. Available at http://www.booz. com/global/home/what-we-think/reports-white-papers/article-display/from-campaignscapabilities-impact-social, 10.

46 Ibid, 9.

$47 \quad$ Bajde, D., Koklic, M.S., Bajde, J. (2015): “Back to consumption and production? Prosumers negotiating the WMG lockdown on YouTube. "Journal of Consumer Behaviour, 14, 297306.

48 Toffler, A. (1980): The third wave, New York: William Morrow.

49 See: Collins, S. (2010): “Digital Fair: Prosumption and the Fair Use Defence." Journal of Consumer Culture, 10, 37-55.; Comor, E. (2011): "Contextualizing and Critiquing the Fantastic Prosumer: Power, Alienation and Hegemony." Critical Sociology, 37, 309-327.; Cook, W. (1997): "World Wide Wake-Up Call." Journal of Advertising Research MarchApril, 5.; Davis, J. (2012): "Prosuming Identity: The Production and Consumption of Transableism on Transabled.org." American Behavioral Scientist, 56, 596-617.; Rey, P. (2012): "Alienation, Exploitation, and Social Media." American Behavioral Scientist, 56, 399-420.; Ritzer, G., Jurgenson, N. (2010): "Production, Consumption, Prosumption: The Nature of Capitalism in the Age of the Digital Prosumer." Journal of Consumer Culture, 10, 13-36.; Ritzer, G., Dean, P., Jurgenson, N. (2012): "The Coming of Age of the Prosumer." American Behavioral Scientist, 56, 379-398.

50 See: Harwood, T., Garry, T. (2014): “Co-creation and ambiguous ownership within virtual communities: the case of the Machinima community." Journal of Consumer Behaviour, 13, 148-156.; Prahalad, C.K., Ramaswamy, V. (2002): "The co-creation connection." Strategy and Business, 27, 51-60.; Prahalad, C.K., Ramaswamy, V. (2004): The future of competition: Co-creating unique value with customers, Boston: Harvard Business Review Press.; Prahalad, C.K., Krishnan, M.S. (2008): The new age of innovation: Driving co-created value through global networks, NewYork: McGraw-Hill. 
producer and the consumer; and prosumption involves a combination of production and consumption. ${ }^{51}$ It follows that companies must not only communicate with users of social media/consumers, but also to respond to their demands. Otherwise, they may lose their customers, i.e. business - in the long term. So, consumers can control not only the communications, but also the business of the companies.

Based on these sources of power of digital consumers, the following hypotheses have been set.

- Hypothesis 1: The more numerous consumers on social media, the greater the market power of digital consumers.

- Hypothesis 2: The more connected consumers are through social media, the greater the market power of digital consumers.

- Hypothesis 3: The more informed consumers are through social media, the greater the market power of digital consumers.

- Hypothesis 4: The more mobile consumers are through social media, the greater the market power of digital consumers.

- Hypothesis 5: The more ability consumers have to control communications through social media, the greater the market power of digital consumers.

- Hypothesis 6: The more ability consumers have to control business through social media, the greater the market power of digital consumers.

\section{Methodology}

The primary data were collected through observation. We have observed online behaviour of the students at the Megatrend University - what they demand from the university and the fulfilment of these demands. Students have formed a forum (The Forum of Megatrend University students), they are present on Facebook and so on. The Facebook group of Megatrend Info - The Forum of Megatrend University students has had 4,605 likes. Observational research has included the behaviour of the above mentioned groups from their establishment (The Forum from October 2006, and the Facebook group from 2010).

Secondly, additional survey was intended to answer the research question - whether there has been a change in marketing activities, business and relationships in Megatrend University due to students' requirements? Data were collected from interviews in the marketing departments, Vice Deans of Academic Affairs of two faculties and 10 teachers (within the above university).

$51 \quad$ Rakic, B., Rakic, M. (2014): “Integrated Marketing Communications Paradigm in Digital Environment: The Five Pillars of the Integration.” Megatrend Review, 11, 187-204. 


\section{Results}

The results of the observational research show that students are more active on the forum, compared to the Facebook group. As for the topics in the forum related to the university, students share information on courses, lectures, exam experiences etc. Some teachers are also active forum members. Students have connected with each other through forums online and have worked on the admission of their representatives by certain representatives of the University (e.g. Rector, Pro-Rector, executive director etc.) so that students' representative can make a specific request for an extra examination period. The application was subsequently accepted. Also, a number of other students' requirements were accepted like organising student internships ("Mega career"), benefits for employed students, greater number of preliminary exams, humanitarian action ("Mega Heart") and so on. On the other hand, not all the requirements were accepted, but when the right arguments were presented to the students, they accepted them. A great number of students are online; they are active, they share information about faculties at the university, as well as about other topics of their (like most young people) interest; they may be the initiators of communication with University representatives and other employees, they communicate with each other in real time and affect changes of certain activities at the University if the requirements are real (as shown in examples).

Via Facebook, students are informed about their initiatives and results, such as, e.g. specializing at foreign faculties, engaging in projects, cooperating with the business entities and practice at companies, taking part in domestic and foreign students' competitions, learning foreign languages (e.g. Chinese, Japanese etc.), communicating with the rector and deans, introducing new subjects, changing the methods of teaching, engaging visiting teachers, accepting additional examination terms, changing the price for services etc. Students organize different events significant for the society, such as, e.g. helping people affected by floods, campaigns for voluntary blood donations etc. Students express their attitudes of needed changes in the society, e.g. by presenting the attitudes of Megatrend University of the strategy of higher education by taking part at a public discussions and so on.

In addition to the observational research of students' behaviour (especially in the aforementioned forum), another survey was conducted. Out of ten interviewed teachers, two are active participants, three are passive "activity monitors" and five do not monitor the activities of the forum. Teachers who are active participants in the forum as advantages of communication via forum mentioned - direct communications with students in real time and the ability to respond rapidly which is important when lot of "disinformation" is posted in the forum. Teachers who only passively monitor activities in the forum as a significant advantage of the forum state - a fast and simple collection of 
information on the students' attitudes towards a particular course and teacher. Vice Deans of Academic Affairs have stated that they were in a position to deal with the demands of students who got organised through forums (the requirements for humanitarian engagement, the allowing of an additional examination period, organising student internships, etc.). Then, when the students had justifiable requirements, they could meet them. In some cases, they had to change plans and activities because of students' feasible demands. The marketing department has stated that Megatrend University is up to date with the changes in digital environment; it is present in social media such as Facebook, Twitter and YouTube, and ready for communications through social media, both with students and with all stakeholders.

\section{Discussion and conclusion}

Some initiatives and proposals on the above forum failed to gather a larger number of students, so that the desired results of the topic starters and the initiators of proposals were not achieved, and thus forth, they did not affect marketing activities and business of the University. This is in accordance with the first and second initial hypothesis. Students as forum users, were not equally informed of all the issues and proposals. Whenever they were better informed about the problem, topic and the actors of communications, they had more power. This is in accordance with the third hypothesis. Mobile phones helped students a lot (especially the "organisers and initiators") with online organising of the offline events. This is in accordance with the fourth hypothesis. Through forums, Facebook groups and other social media students can be initiators of communications in real-time, so that they can increasingly control the communications, which further increases their market power. This is in accordance with the fifth hypothesis. Finally, students can affect marketing activities and business of the university, which increases their market power, which is in accordance with the sixth hypothesis. In short, this research can leads us to the conclusion that the more numerous the students are, more connected, more informed, more mobile, they can more affect the communications, marketing activities and the business of the University.

A tweet uploaded on $13^{\text {th }}$ Oct. 2011 (Megatrend Info on Twitter): An Initiative for October-3! (Join Our Forces) is an excellent one for the conclusion. The mentioned tweet is an inseparable part of the students' online "fight" for the additional October Examination Term. Over 30,000 members of The Forum of Megatrend University and almost 5,000 fans of the Facebook Group of Megatrend Info can stand for a significant "Army" for both the students and the university.

Online communities of people sharing similar interests and goals (e.g. Facebook groups) can have a bigger power. Online communities need to "join 
their forces" in order for them to initiate, organize and implement online and offline activities. A conclusion can be drawn that the digital consumers have the market power only if they are connected to each other and are aware of their power. Figuratively speaking, "one bee can achieve almost nothing, but the bee community can achieve a lot." The similar thing happens with the digital consumers. On the other hand, companies can see the power of digital consumers as an opportunity (rather than a threat) and direct their marketing activities towards social media marketing, the marketing community, the content, mobile marketing, interactions and the WOMM, engagement and collaboration with customers (and stakeholders).

\section{Literature}

- Alberici, AI., Milesi, P. (2013): "The Influence of the Internet on the Psychosocial Predictors of Collective Action." Journal of Community \& Applied Social Psychology, 23, 373-388.

- Aldás, E.N., Murphy, J.M. (2013): "Occupy Movements and the Indignant Figure." Peace Review - A Journal of Social Justice, 25, 333-335.

- Aldás, E.N., Pinazo D. (2013): "Communication and Engagement for Social Justice." Peace Review - A Journal of Social Justice, 25, 343-348.

- Aldás, E.N., Smith, M.B. (2015): "Communication, Civil Society, and Social Change." Comunicar Journal - Special Issue - Call for papers. Available at http://www.revistacomunicar.com/pdf/call/call-47-en.pdf

- Anklam, P. (2009): “Ten years of net work.” The Learning Organization, 16, 415-426.

- Aprimo (2011): Insights to Help Advance Digital Marketing. Available at http://research.itpro.co.uk/content12192

- Aragon-Correa, J.A., Cordon-Prozo, E. (2005): “The influence of strategic dimensions and the environment on the introduction of internet as innovation into small and medium-sized enterprises." Technology Analysis and Strategic Management, 17, 2205-218.

- August, C., Liu, J.H. (2015): “The Medium Shapes the Message: McLuhan and Grice Revisited in Race Talk Online." Journal of Community \& Applied Social Psychology, 25, 232-248.

- Aula, P. (2010): "Social media, reputation risk and ambient publicity management." Strategy \& Leadership, 38, 43-49.

- Bajde, D., Koklic, M.S., Bajde, J. (2015): "Back to consumption and production? Prosumers negotiating the WMG lockdown on YouTube. " Journal of Consumer Behaviour, 14, 297-306.

- Ballantine, P.W., Stephenson, R.J. (2011): "Help me, I'm fat! Social support in online weight loss networks." Journal of Consumer Behaviour, 10, 332-337. 
- Batinic, B., Goritz, A. (2009): "How Does Social Psychology Deal with New Media." Social Psychology, 40, 3-5.

- Berthon, P.R., Pitt, L.F., McCarthy, I., Kates S. (2007): When customers get clever: Managerial approaches to dealing with creative consumers. Business Horizons, 50, 39-48.

- Booth, N., Matic, J. (2011): "Mapping and leveraging influencers in social media to shape corporate brand perceptions." Corporate Communications: An International Journal, 16, 184-191.

- Boyd, S. (2009): Social tools defined. Available at http://stoweboyd.com/ post/823716577/social-tools-defined

- Chen, Y., Fay, S., Wang, Q. (2011): “The Role of Marketing in Social Media: How Online Consumer Reviews Evolve." Journal of Interactive Marketing, 25, 85-94.

- Collins, S. (2010): "Digital Fair: Prosumption and the Fair Use Defence." Journal of Consumer Culture, 10, 37-55.

- Comor, E. (2011): "Contextualizing and Critiquing the Fantastic Prosumer: Power, Alienation and Hegemony." Critical Sociology, 37, 309-327.

- Contreras, E. (2013): Social State: Thoughts, stats, and stories about the state of social media in 2013. Social Nerdia.

- Cook, W. (1997): "World Wide Wake-Up Call." Journal of Advertising Research March-April, 5.

- Davis, J. (2012): "Prosuming Identity: The Production and Consumption of Transableism on Transabled.org." American Behavioral Scientist, 56, 596-617.

- Denning, S. (2010): "Managing the threats and opportunities of the open corporation." Strategy \& Leadership, 38, 16-22.

- Fleck, J. (1997): “Contingent knowledge and technology development. Technology Analysis and Strategic Management, 9, 383-398.

- Fish, J. (2010): "Power to the People Is at the Heart of Social Media Channels!" Credit Union Times, 21, 10.

- Galera, C.G., Hurtado, M.H., Muñoz, C.F. (2014): "Engaged Youth in Internet. The Role of Social Networks in Social Active Participation." Comunicar Journal, $43,35-43$.

- Hamill, A.C., Stein, C.H. (2011): "Culture and empowerment in the Deaf community: An analysis of internet weblogs." Journal of Community \& Applied Social Psychology, 21, 388-406.

- Hanna, R., Rohm, A., Crittenden, V. (2011): "We're all connected: The power of the social media Ecosystem." Business Horizons, 54, 265-273.

- Harwood, T., Garry, T. (2014): "Co-creation and ambiguous ownership within virtual communities: the case of the Machinima community." Journal of Consumer Behaviour, 13, 148-156. 
- Heinonen, K. (2011): "Consumer activity in social media: Managerial approaches to consumers' social media behavior." Journal of Consumer Behaviour, 10, 356-364.

- Internet World Stats. (2017): World Internet Users and 2017 Population Stats. Available at http://www.internetworldstats.com/stats.htm

- Kim, W., Jeong, OR., Lee, SW. (2010): “On social Web sites. ”Information Systems, 35, 215-236.

- Li, C. (2010): Open Leadership: How Social Technology Can Transform the Way You Lead. Jossey-Bass: San Francisco.

- Mangold, G., Faulds, D. (2009): "Social media: The new hybrid element of the promotion mix." Business Horizons, 52, 357-365.

- Niland, P., Lyons, A.C., Goodwin, I., Hutton, F. (2015): "Friendship Work on Facebook: Young Adults' Understandings and Practices of Friendship." Journal of Community \& Applied Social Psychology, 25, 123-137.

- Obst, P., Stafurik, J. (2010): “Online we are all able bodied: Online psychological sense of community and social support found through membership of disability-specific websites promotes well-being for people living with a physical disability." Journal of Community \& Applied Social Psychology, 20, 525-531.

- O’Hare, N., Murdock, V. (2012): "Modeling locations with social media." Information Retrieval, 16, 30-62.

- Pehlivan, E., Sarican, F., Berthon, P. (2011): "Mining messages: Exploring consumer response to consumer- vs. firm-generated ads." Journal of Consumer Behaviour, 10, 313-321.

- Pew Internet \& American Life Project. (2013): Web 2.0. Available at http:// www.pewinternet.org/topics/Web-20.aspx?typeFilter $=5$

- Prahalad, C.K., Ramaswamy, V. (2002): “The co-creation connection.” Strategy and Business, 27, 51-60.

- Prahalad, C.K., Ramaswamy, V. (2004): The future of competition: Co-creating unique value with customers, Boston: Harvard Business Review Press.

- Prahalad, C.K., Krishnan, M.S. (2008): The new age of innovation: Driving co-created value through global networks, NewYork: McGraw-Hill.

- Rakic, B., Rakic, M. (2014): "Integrated Marketing Communications Paradigm in Digital Environment: The Five Pillars of the Integration." Megatrend Review, 11, 187-204.

- Rakić, B., Rakić, M. (2015): Digitalni marketing - integrisani pristup digitalnim marketinskim aktivnostima, monografija. Beograd: Zavod za udžbenike.

- Rakic, B., Rakic, M. (2017a): From Marketing Myopia to Contemporary Marketing: Transformations in Marketing in the Context of Digitalization and Sustainability (Integration of Traditional, Digital, Co-Creative and Sustainability-Oriented Mindsets Inside Actors in Contemporary Marketing). E-Book, available at eBook retailers: Amazon.com - Kindle Store, etc.; Kindle Edition 
ASIN: B06WGV26DT https://www.amazon.com/Marketing-Myopia-Contemporary-Through-Evolutions-ebook/dp/B06WGV26DT/ref=sr_1_2?s=digitaltext\&ie=UTF8\&qid=1487803402\&sr=1-2\&keywords=marketing + myopia or https://www.books2read.com/u/bMGKkk

- Rakic, B., Rakic, M. (2017b): Facebook or the "Book of Faces" as a database for customer profiles, marketing communications and applications. 21st International Scientific Conference on Economic and Social Development. Book of Proceedings: Economic and Social Development, 48-58.

- Ramsey, G. (2006): Digital marketing strategies in the age of consumer control. Available athttp://www.asc.upenn.edu/courses/comm530/secure/Fall\%20 2006/Digital\%20Marketing\%20Strategies.pdf

- Rey, P. (2012): "Alienation, Exploitation, and Social Media." American Behavioral Scientist, 56, 399-420.

- Ritzer, G., Jurgenson, N. (2010): "Production, Consumption, Prosumption: The Nature of Capitalism in the Age of the Digital Prosumer." Journal of Consumer Culture, 10, 13-36.

- $\quad$ Ritzer, G., Dean, P., Jurgenson, N. (2012): “The Coming of Age of the Prosumer." American Behavioral Scientist, 56, 379-398.

- Ruiz, R.G., García, A.R., Rosell, M.M.R. (2014): "Media Literacy Education for a New Prosumer Citizenship." Comunicar Journal, 43, 15-23.

- Schiller, D. (1999): "Deep impact the web and the changing media economy." Info - The journal of policy, regulation and strategy for telecommunications, $1,35-51$.

- $\quad$ Scott, M. (2011): “Social Media Flurry”. OfficePro, 71, 38-41.

- Segbers, R. (2010): "Go where the customers are - Marketing (and managing) your patient experience with social media". Marketing health services, 30, 22-25.

- $\quad$ Siddiquee, A., Kagan, C. (2006): “The internet, empowerment, and identity: an exploration of participation by refugee women in a Community Internet Project (CIP) in the United Kingdom (UK)." Journal of Community \& Applied Social Psychology, 16, 189-206.

- Singh, S. (2005): Web 2.0: Connectedness, sharing, and the social. Available at http://www.siliconindia.com/magazine_articles/Web_20Connectedness_ sharing_and_the_social-NLF651991104.html

- $\quad$ Singh, T., Veron-Jackson, L., Cullinane, J. (2008): “Blogging: A new play in your marketing game plan.” Business Horizons, 51, 281-292.

- Socialbakers. (2015): Facebook Pages Stats. Available at http://www.socialbakers.com/statistics/facebook/pages/total/page-1-3/

- Su, P., Wang, L., Yan, J. (2018): “How users' Internet experience affects the adoption of mobile payment: a mediation model." Technology Analysis and Strategic Management, 30, 186-197.

- Toffler, A. (1980): The third wave, New York: William Morrow. 
- Vollmer, C., Precourt, G. (2008): Always on: Advertising, marketing, and media in an era of consumer control. McGraw-Hill: New York.

- Vollmer, C., Premo, K. (2012): From Campaigns to Capabilities-The Impact of Social Media on Marketing and Beyond, Booz \& Company Inc. Available at http://www.booz.com/global/home/what-we-think/reports-white-papers/ article-display/from-campaigns-capabilities-impact-social

- Walmsley, A. (2010): New media needs new PR. Available at http://www. marketingmagazine.co.uk/article/985566/andrew-walmsley-digital-newmedia-needs-new-pr

- Weber, T. (2010): Why companies watch your every Facebook, YouTube, Twitter move. Available at http://www.bbc.co.uk/news/business-11450923 


\section{TRŽIŠNA MOĆ DIGITALNIH POTROŠAČA U POVEZANOM SVETU 24/7/365}

Ovaj rad analizira i predstavlja izvore tržišne moći digitalnih potrošača i marketinške mogućnosti za kompanije u stalno povezanom svetu (24/7/365). Sprovedeno je istraživanje o uticaju studenata povezanih preko društvenih medija na promene na fakultetu $i$ u društvu. Tržišna moć se preusmerava od kompanija ka digitalnim potrošačima. Ključni izvori moći digitalnih potrošača su brojnost, povezivanje sa drugim potrošačima, povećana informisanosrt $i$ znanje, mobilnost $i$ kao rezultat - kontrola komunikacija $i$ uticaj na poslovanje organizacija. Brojni, povezani, informisani i mobilni potrošači mogu da kontrolišu komunikacije i poslovanje preduzeća. Digitalni potrošači imaju moć $i$ to ne bi trebalo posmatrati kao opasnost, već kao mogućnost. Zbog toga su izvori tržišne moći digitalnih potrošača i marketinške mogućnosti predstavljeni u "obliku saća”. Zaključak je da digitalni potrošači imaju tržišnu moć samo ako su povezani jedni s drugima i svesni svoje moći. Figurativno govoreći, "jedna pčela ne može postići skoro ništa, ali zajednica može." Slična situacija je kod digitalnih potrošača.

Ključne reči: digitalni potrošači, društveni mediji, tržišna moć, povezani svet, marketinške mogućnosti 